\title{
Environmental advantages of composite fuels based on industrial wastes and different ranks of coal
}

\author{
Galina Nyashina, ${ }^{1, *}$ \\ ${ }^{1}$ National Research Tomsk Polytechnic University, Tomsk, 634050, Russia
}

\begin{abstract}
Thermal power plants and boiler units generate most of the anthropogenic emissions around the world. A promising solution to many problems that heat and power industry is facing today would be switching from conventional coal dust combustion to composite liquid fuels (CLF). These are also known as coal-water slurries containing petrochemicals (CWSP). Here, we perform an experimental study of the most hazardous anthropogenic emissions (sulfur and nitrogen oxides) from the combustion of high-potential CWSP. We identify the main benefits and potential drawbacks of using CWSP in heat and power industry. A set of components and additives to CWSP are explored that significantly affect the environmental and energy performance of fuels. The anthropogenic emissions from the combustion of CWSP made of widespread coal and oil processing wastes are no higher than those from coal dust combustion. Using specialized additives to CWSP, we can change the concentrations of NOx and SOx several times. The most appealing additives to CWSP are sawdust, straw, charcoal, limestone, and glycerol.
\end{abstract}

\section{Introduction}

Fossil fuels are the primary sources of heat and electricity in many countries. In the global energy mix, they account for over $80 \%$ [1-3], $20 \%$ of which is covered by coal. World energy production relies heavily on coal-fired thermal power stations and boiler plants. New coal-burning power stations and boiler plants appear every year, despite severe environmental implications. As the energy demand increases, coal-fired thermal power stations and boiler plants will only reinforce their leading positions in the coming decades. For instance, a report by the International Energy Agency [4] states that almost $41 \%$ of the world's electricity in 2013 was generated using coal. This number went up to $46 \%$ [4] in $2014-2016$ and is expected to reach $50-52 \%$ in $2017-2020$.

The mass usage of coal causes severe adverse environmental impacts and disrupts the ecological balance $[5,6]$. Coal combustion leads to high emissions of nitrogen- and sulfurcontaining oxides $\left(\mathrm{NO}_{\mathrm{x}}\right.$ and $\left.\mathrm{SO}_{\mathrm{x}}\right)$, volatile organic compounds (ash, soot, and dust), carbon dioxide $\left(\mathrm{CO}_{2}\right)$, as well as various traces of metals that can dissipate in the atmosphere over vast areas and have a significant negative effect on human health $[7,8]$.

\footnotetext{
* Corresponding author: gsn1@tpu.ru
} 
The one considered the most promising is boosting the coal combustion efficiency by producing coal-based composite fuels: coal-water slurries with or without petrochemicals. Such an alternative to the conventional use of coal does not only alleviate global environmental problems but also provides a significant effect in terms of economy and energy performance [9-11]. In particular, involving low-rank coals and numerous coal and oil processing wastes into the process expands the scope of raw materials for the heat and power industry [11].

Coal-water slurry fuel (a mixture of water, coal dust, and chemical additives) is a viscous, stable, fire- and explosion-safe slurry, which is environmentally friendly at all stages of production and usage. Its fuel base consists of power-generating coals as well as non-power coals and coal sludge with a concentration of solid substances of no less than $60 \%$ [12]. Production of composite power fuels is the next step in the development of coalwater slurry technologies.

At the same time, there are some problems with the implementation of CWS technologies. Coal-water slurries are inferior to high-carbon fuels in the proportion of carbon. For this reason, they are notable for lower combustion temperatures and heat release (heat of combustion). Moreover, their erratic ductility makes it necessary to use chemical additives and stifles their advancement. This problem can be resolved by adding even as little as $10-15 \mathrm{wt} . \%$ of liquid fuel component to coal-water slurry fuels. This is how coal-water slurries containing petrochemicals are produced [11, 12]. The following substances can serve as liquid fuel components: waste industrial and motor oils, flammable liquids, emulsions, slurries, industrial wastes, etc. The range of these raw materials is growing rapidly [11].

The objective of this work is to undertake a comprehensive study of the environmental consequences brought about by the combustion of CLF slurries and coals of different ranks with high-potential additives.

\section{Experimental setup and methods}

To study the anthropogenic emissions from the combustion of coals as well as highpotential CWS and CWSP, we used an experimental setup similar to the one used in [13]. The key elements that ensured the continuous experimental studies included a combustion chamber, gas analyzing equipment, and high-speed recording devices (fig. 1).

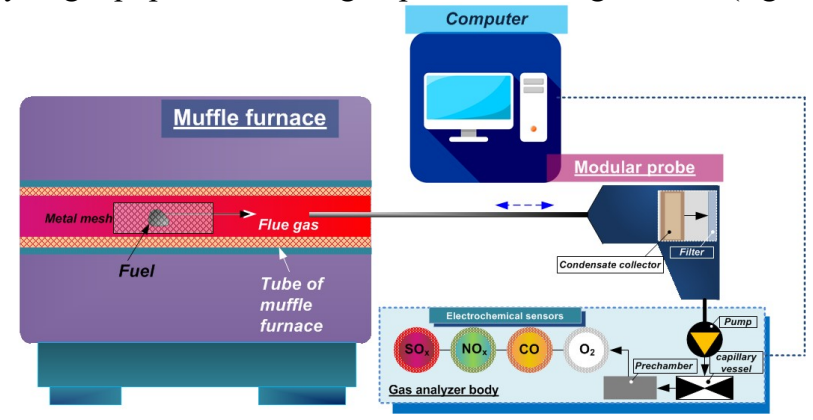

Fig. 1. The scheme of the experimental stand.

The method we used to determine the amount of emissions from fuel combustion involved the following procedures: preparing a fuel sample, placing it into a combustion chamber, and sampling the emitted gases. We produced CWS and CWSP by the procedure from [38] in laboratory conditions (temperature $20{ }^{\circ} \mathrm{C}$, pressure $101.3 \mathrm{kPa}$, relative humidity $80 \%$ ). The prepared fuel sample was placed in a combustion chamber (muffle furnace) by means of a positioning mechanism. A modular probe collected samples of flue 
gases in the measuring area during fuel combustion in the chamber [13]. The gaseous products released during heating, ignition, and combustion of fuel in the muffle furnace were recorded and analyzed by the emissions monitoring system [13]. The mass of the sample was $1 \mathrm{~g}$. Only a portion this small and a model combustion chamber [13] make it possible to meet the objectives of this research with the required degree of accuracy.

\section{Results and discussion}

Fig. 2 presents the concentrations of the main anthropogenic emissions $\left(\mathrm{SO}_{x}, \mathrm{NO}_{\mathrm{x}}\right)$ from the combustion of conventional coal dust and coal-water fuel (filter cake) versus coal-water slurries containing petrochemicals and additives. The figure clearly shows the differences between the main anthropogenic emissions when the additives under study are used.
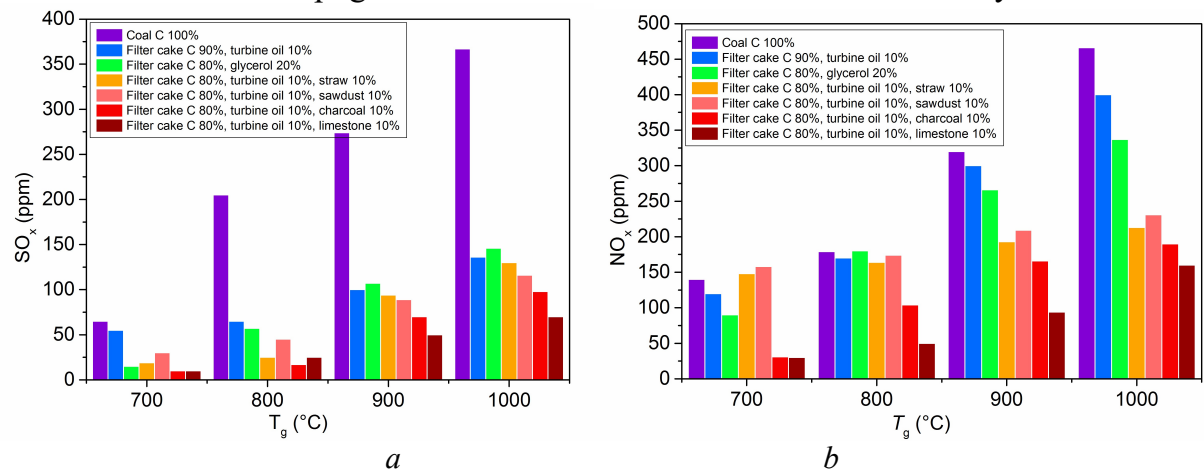

Fig. 2. Concentrations of $\mathrm{SO}_{\mathrm{x}}(a)$ and $\mathrm{NO}_{\mathrm{x}}(b)$ emissions versus combustion temperature

The increased amount of water phase in the slurries reduced the concentrations of all the anthropogenic emissions under study by $10-40 \%$. During the CWSP combustion, water (30-50\%) serves as an oxidizer, which accelerates coal burnout. Using CWS makes power facilities more cost-effective by decreasing the underburning and reducing the contamination of heating surfaces in boiler units. An increase in water phase amount reduces the underburning (CO). Water in the form of hot vapor in the combustion zone provides a finer distribution of the carbon basis due to microexplosions of slurry droplets [15]. As a result, due to its more complete burnout, the amount of soot, benzapyrene, and secondary hydrocarbons in the waste gases is reduced. During the thermal dissociation of water, free molecules of oxygen and hydrogen are released: $\mathrm{H}_{2} \mathrm{O}=\mathrm{H}_{2}+\mathrm{O}_{2}$.

The oxygen formed during this reaction enhances combustion, whereas hydrogen and carbon monoxide act as reductants, decreasing the content of nitrogen and sulfur oxides in the flue gases: $\mathrm{NO}_{\mathrm{x}}+\mathrm{H}_{2}=\mathrm{N}_{2}+\mathrm{H}_{2} \mathrm{O} ; \mathrm{NO}_{\mathrm{x}}+\mathrm{CO}=\mathrm{N}_{2}+\mathrm{CO}_{2} ; \mathrm{SO}_{\mathrm{x}}+\mathrm{H}_{2}=\mathrm{S}+\mathrm{H}_{2} \mathrm{OSO}_{\mathrm{x}}+\mathrm{CO}=\mathrm{S}+\mathrm{CO}_{2}$.

Water, as a component of composite liquid fuel, decreases the temperature and rate of adiabatic combustion, which reduces the anthropogenic emissions of $\mathrm{NO}_{\mathrm{x}}$ and $\mathrm{SO}_{\mathrm{x}}$.

We consider pine sawdust, which is a wood industrial waste. The presence of $10 \%$ of sawdust in the CWSP provides a twofold reduction in the concentration of nitrogen oxides formed during fuel combustion (150-200 ppm vs. 350-650 ppm for CWSP based on a filter cake and turbine oil). The established decrease in the formation of fuel nitrogen oxides has several reasons. First, sawdust intensifies ignition (temperatures of thermal decomposition and ignition of sawdust are $200-300{ }^{\circ} \mathrm{C}$ lower than those of filter cakes) and increases the yield of carbon monoxide, which takes part in the reducing reactions forming free $\mathrm{N}_{2}$ $\left(\mathrm{NO}_{\mathrm{x}}+\mathrm{CO}=\mathrm{N}_{2}+\mathrm{CO}_{2}\right.$. Second, the Fe content in sawdust leads to more reactions of $\mathrm{NO}_{\mathrm{x}}$ reduction and $\mathrm{N}_{2}$ formation $\left(2 \mathrm{Fe}+{ }_{3} \mathrm{NO}=3 / 2 \mathrm{~N}_{2}+\mathrm{Fe}_{2} \mathrm{O}_{3}\right)$. Thus, in terms of $\mathrm{NOx}$ emissions, the priority of slurries containing $10 \%$ of sawdust becomes obvious. The emission of sulfur 
dioxides from the combustion of CWSP and CWSP including sawdust is comparable and does not exceed $100 \mathrm{ppm}$.

The experiments have revealed that the addition of charcoal may have a significant effect on the fuel ecology. Therefore, its use as an additive requires rational consumption. For instance, in order to reach the optimal environmental performance (Fig. 2), it is necessary to add $10 \%$ of charcoal to the fuel based on a filter cake and used turbine oil. Such a concentration makes it possible to reduce the main anthropogenic emissions $\left(\mathrm{NO}_{\mathrm{x}}\right.$ and $\mathrm{SO}_{2}$ ) with a negligible rise in the cost of the initial fuel but a significant improvement to the energy performance.

The experimental data show that adding straw to CWSP significantly reduces gas emissions (Figs. 2). Thermochemical conversion (combustion) releases compounds of alkaline and alkaline-earth metals, which straw wastes contain in abundance. These compounds react with sulfur oxides (e.g., $2 \mathrm{CaO}+2 \mathrm{SO}_{2}+\mathrm{O}_{2}=2 \mathrm{CaSO}_{4}$ ) to form substances that remain in the coal ash and contribute to sulfur retention reactions due to gaseous sulfur trioxide absorption. The products of such reactions are $\mathrm{KCl}$ and $\mathrm{K} 2 \mathrm{SO} 4, \mathrm{NaCl}$ and $\mathrm{Na} 2 \mathrm{SO} 4$, and a small amount of $\mathrm{Ca}$ and $\mathrm{Mg}$-sulfates, which form most of the residue on thermally loaded surfaces in boiler units. On the other hand, due to high content of alkaline metals, the melting temperature of straw ash is relatively low. Consequently, there may be slag deposits on low-temperature surfaces. Moreover, high content of chlorine in the straw may aggravate the corrosion of boiler elements.

The curves in Fig. 2 show the concentrations of the main anthropogenic emissions for a slurry with glycerol. They are overall similar to those obtained for straw, sawdust, and charcoal. $\mathrm{SO}_{4}$ and $\mathrm{NO}_{x}$ concentrations are much lower, since glycerol contains virtually no sulfur or nitrogen. Low adiabatic temperatures of the glycerol flame are yet another reason for a reduction in the so-called fuel nitrogen oxides. An important factor affecting the emission of sulfur oxides is the content of sodium salts in glycerol.

The analysis of flue gases has shown (Figs. 2) that the average concentrations of sulfur and nitrogen oxides throughout the temperature range of 700 to $1,000{ }^{\circ} \mathrm{C}$ are lower than for all the other compositions under study. The decrease in the emissions when using lime results from a reduction in the natural sulfur and nitrogen content. Lime compensates for the liquid fuel component, which makes a massive contribution to the formation of the main fuel oxides

\section{Conclusions}

This is a comprehensive research into the environmental and energy benefits and drawbacks of a large-scale use of CWSP based on industrial wastes and coals of different ranks. Using CWSP as fuel is an effective way to recover industrial wastes, in particular, used oils and coal processing wastes. Anthropogenic emissions from the combustion of waste-based CWSP are no higher than those from the conventional coal dust combustion.

This work was supported by the Russian Foundation for Basic Research (project 18-43-700001) and project VIU-ISHFVP-184/2018.

\section{References}

1. J. Xu, Y. Yang, Y.-W. Li, Fuel. 152, 122 (2015)

2. F.-Q. Su, K.-I. Itakura, G. Deguchi, K.Ohga, Appl. Energy. 189, 142 (2017)

3. F. Liu, T. Lyu, L. Pan, F. Wang, Energy Policy. 105, 398 (2017)

4. World Energy Outlook Special Report 2016: Energy and Air (International Energy Agency, New York, 2016) 
5. M. Rahman, D. Pudasainee, R. Gupta, Fuel Process. Technol. 158, 35 (2014)

6. B. Hampf, K.L. Rodseth, 50, 140 (2015)

7. S. Li, T. Xu, P. Sun, Q. Zhou, H. Tan, S. Hui, Fuel. 87, 723 (2008)

8. H.M. Ertugrul, M. Cetin, F. Seker, E. Dogan, Ecol. Indic. 67, 543 (2016) 543-555.

9. I.G. Nodelman, S.V. Pisupati, S.F. Miller, A.W. Scaroni, J. Hazard. Mater. 74, 47 (2000)

10. J. Liu, X. Jiang, L. Zhou, H. Wang, X. Han, J. Hazard. Mater. 167, 817 (2009)

11. D.O. Glushkov, P.A. Strizhak, M.Yu. Chernetskii, Therm. Eng. 63, 707 (2016) G.S. Khodakov, Therm. Eng. 54, 36 (2007)

12. M.A. Dmitrienko, G.S. Nyashina, P.A. Strizhak, J. Hazard. Mater. 338, 148 (2017) 